\title{
Pengaruh Penggunaan Metode Problem Based Learning terhadap Kemampuan Pemecahan Masalah Peserta Didik pada Mata Pelajaran Ekonomi
}

\section{The Effect of The Use of Problem Based Learning Method On The Problem of Troubleshooting Education in Economic Learning}

\author{
Santi $^{\text {a,1* }}$, Ikaputera Waspada ${ }^{\text {b, } 2 \text {, Sumartini }}{ }^{\text {c,3 }}$ \\ a,b Program Studi Pendidikan Ekonomi, Sekolah Pascasarjana, UPI Bandung \\ ${ }^{1}$ santi@upi.edu*,, ${ }^{2}$ Ikaputerawaspda@upi.edu, ${ }^{3}$ sumartinifpeb@upi.edu \\ *korespondensi penulis
}

\begin{tabular}{l}
\hline Informasi Artikel \\
\hline Kata Kunci: \\
Problem Based Learning, \\
Pemecahan Masalah \\
Pembelajaran Ekonomi
\end{tabular}

Pembelajaran Ekonomi

\begin{abstract}
ABSTRAK
Tujuan dari penelitian ini yaitu untuk menganalisis perbedaan kemampuan pemecahan masalah peserta didik yang menggunakan metode problem based learning dengan metode konvensional (ceramah, tanya jawab). Penelitian ini dilakukan di SMA Negeri 1 Rengasdengklok Kabupaten Karawang, dengan subjek penelitian yaitu kelas XI IIS 1 dan kelas XI IIS 2 dengan jumlah 67 peserta didik. Metode yang digunakan dalam penelitian ini adalah quasi semu (quasi eksperiment), untuk mengetahui hasil dari perlakuan yang dilakukan oleh peneliti dengan menggunakan 2 metode. Hasil dari analsis data yang dilakukan oleh peneliti menunjukan bahwa terdapat peningkatan kemampuan pemecahan masalah atau terdapat pengaruh positif penggunaan metode problem based learning terhadap kemampuan pemecahan masalah peserta didik dibandingkan dengan metode konvensional pada mata pelajaran ekonomi dengan sub judul materi perpajakan. Dengan hasil tersebut peneliti menyarankan agar penelitian selanjutnya bisa menggunakan metode problem based learning pada mata pelajaran ekonomi dengan sub judul materi yang lain.
\end{abstract}

\begin{abstract}
The purpose of this study is to analyze differences in the problem solving abilities of students who use the problem based learning method with conventional methods (lecture, question and answer). This research was conducted at SMA Negeri 1 Rengasdengklok, Karawang Regency, with research subjects namely class XI IIS 1 and class XI IIS 2 with a total of 67 students. The method used in this study is quasi quasi (quasi experiment), to determine the results of the treatment carried out by researchers using 2 methods. The results of data analysis conducted by researchers show that there is an increase in problem solving ability or there is a positive influence on the use of problem based learning methods on students' problem solving abilities compared to conventional methods in economic subjects with taxation material subtitles. With these results the researchers suggest that further research can use the problem based learning method in economic subjects with other material subtitles.
\end{abstract}

\section{Pendahuluan}

Pembelajaran abad ke-21 ditandai sebagai abad keterbukaan atau abad globalisasi, artinya kehidupan manusia pada abad ke-21 mengalami perubahan-perubahan yang fundamental yang berbeda dengan tata kehidupan dalam abad sebelumnya. Abad 21 ini menuntut kualitas dalam segala usaha dan hasil kerja manusia, sehingga dengan sendirinya abad 21 ini mengharapkan sumber daya manusia yang berkualitas (Fernandes, 2019). Manusia yang berkualitas dihasilkan oleh lembaga-lembaga yang dikelola secara profesional sehingga membuahkan hasil unggulan (Sumantri, 2019). Tuntutan-tuntutan yang serba baru tersebut meminta berbagai terobosan dalam berfikir, penyusunan konsep, dan tindakan-tindakan. Dengan kata lain diperlukan suatu paradigma baru dalam 
menghadapi tantangan-tantangan yang baru, demikian kata filsuf Khun. Menurut filsuf Khun (Wijaya et al., 2016) apabila tantangantantangan baru tersebut dihadapi dengan menggunakan paradigma lama, maka segala usaha akan menemui kegagalan. Tantangan yang baru menuntut proses terobosan pemikiran (breakthrough thinking process) apabila yang diinginkan adalah output yang bermutu yang dapat bersaing dengan hasil karya dalam dunia yang serba terbuka (Tilaar, 1998).

Pendidikan abad ke-21 juga menekankan pada kemampuan siswa menyelesaikan masalah secara kreatif dan melaksanakan pembelajaran long-life-learning. Menganalisis permasalahan yang dihadapi kemudian memikirkan penyelesaiannya secara kritis kemudian dengan kreatifitasnya memberikan solusi yang berbeda untuk tiap permasalahan. Kemampuan memecahkan masalah harus didukung dengan kreativitas. Kreativitas dapat membuat individu menemukan berbagai solusi untuk memecahkan masalah, karena mereka memiliki sudut pandang yang berbeda-beda dalam memandang suatu masalah (Mursidik et al., 2015). Kreativitas dipandang sebagai tindakan cerdas yang menciptakan beberapa solusi untuk masalah oleh pandangan asli dan unik (divergen) daripada membatasi solusi dengan kecerdasan dan logika (konvergen) (Beetlestone, 2011).

Dalam melatih para peserta didik agar dapat meningkatkan kemampuan memecahkan masalah dibutuhkan suatu proses pembelajaran yang mengacu pada tujuan pembelajaran yang melihat peningkatan kemampuan pemecahan masalah. Fokus utama dan karakteristik dari mata pelajaran ekonomi adalah kemampuan berfikir kognitif melalui pemecahan masalah.

Berdasarkan hasil observasi yang dilakukan penulis pada mata pelajaran ekonomi siswa kelas XI IPS SMA Negeri 1 Rengasdengklok, diperoleh keterangan bahwa banyak siswa yang tidak berperan aktif selama proses belajar mengajar ekonomi di kelas berlangsung. Hal ini dikarenakan guru masih menggunakan model pembelajaran konvensional. Guru hanya menyampaikan materi pembelajaran dengan ceramah sesuai dengan materi pelajaran yang ada di buku tanpa mengaitkannya dengan kehidupan sehari-hari siswa, sehingga banyak siswa yang merasa bosan dan beranggapan bahwa ekonomi adalah mata pelajaran yang tidak menarik. Bahkan ketika guru memberi kesempatan kepada siswa untuk bertanya, siswa-siswa tersebut hanya diam dan menunduk karena pada dasarnya mereka tidak memahami materi yang yang sedang mereka pelajari. Kemudian dilihat dari aktivitas mereka dalam mengerjakan tugas yang diberikan oleh guru, banyak siswa yang tidak langsung mengerjakannya, seperti acuh tak acuh, banyak yang bercerita, dan aktivitas yang tiak ada kaitannya dengan kegiatan belajar mengajar khususnya dalam bidang studi ekonomi. Bisa dilihat dari hasil pra-penelitian yang dilakukan oleh peneliti pada tabel 1 sebagai berikut:

Tabel 1

Hasil Uji Pra-Penelitian

\begin{tabular}{|c|c|c|c|c|c|c|}
\hline Kelas & Jumah & Rata-rata & \multicolumn{2}{|c|}{ Belum Tuntas } & \multicolumn{2}{|c|}{ Tuntas } \\
\cline { 4 - 7 } & Siswa & Nilai & $<\mathbf{7 5}$ & $\mathbf{\%}$ & $>\mathbf{7 5}$ & $\mathbf{\%}$ \\
\hline XI IPS 1 & 34 & 74,25 & 10 & 29,41 & 24 & 70,59 \\
\hline XI IPS 2 & 33 & 77,20 & 12 & 36,36 & 21 & 63,64 \\
\hline
\end{tabular}

Berdasrkan dari hasil tabel 1.1 bisa dilihat bahwa masih banyak siswa yang belum memenuhi kriteria ketuntasan dalam pembelajaran ekonomi, yaitu sekitar 22 siswa pada 2 kelas dengan jumlah keseleruhan siswa sebanyak 65 siswa. Berdasarkan permasalah di

atas, tujuan penelitian ini adalah untuk menganalisis perbedaan kemampuan pemecahan masalah menggunakan metode problem based learning dengan metode konvensional. 


\section{Kajian Literatur}

Jean Piaget (Oktavianti et al., 2018) menyatakan bahwa teori konstruktivisme adalah pengetahuan yang diperoleh seorang anak yang merupakan hasil dari konstruksi pengetahuan awal yang telah dimiliki dengan pengetahuan yang baru diperolehnya. Hal ini seajalan dengan pernyataan (Paradesa et al., 2017) yang menyatakan bahwa konstruktivisme adalah suatu pendekatan yang berkeyakinan bahwa orang secara aktif membangun atau membuat pengetahuan sendiri dan realitas ditentukan oleh pengalaman orang itu sendiri.

\section{Problem Based Learning}

Problem Based learning dikembangkan sejak tahun 1976-an di McMaster University di Canada dan metode ini sudah merambah ke berbagai jenjang pendidikan. Keunggulan dari metode ini, jenjang pendidikan yang lebih rendah pun sudah mulai menggunakan metode ini. dengan perkembangan yang pesat, rumusannya juga beragam. Salah satu yang cukup mewakili, adalah rumusan yang diungkapkan Prof. Howard Barrows dan Kelson (Amir, 2010, hlm. 21).

Menurut Barbara J. Duch, Problem Based Learning (PBL) merupakan satu metode yang ditandai dengan penggunaan masalah yang ada di dunia nyata untuk melatih peserta didik berfikir kritis dan terampil memecahkan masalah, dan memperoleh pengetahuan tentang konsep yang penting dari apa yang dipelajari (Wijayanto, 2009). Sedangkan Menurut (Alan \& Afriansyah, 2017), Problem Based Learning (PBL) merupakan rangkaian aktivitas pembelajaran yang menekankan kepada proses penyelesaian masalah yang dihadapi secara ilmiah. Pada metode ini pembelajaran dimulai dengan menyajikan permasalahan nyata yang penyelesaiannya membutuhkan kerjasama antara peserta didik dalam kelas (Agustin, 2013).

Metode PBL ini akan lebih efektif jika diterapkan dengan menggabungkan dengan metode yang mendukung peserta didik untuk berpikir rasional dan ilmiah, aktif dan menguasai ilustrasi ilmiah, serta mahir dalam pemecahan masalah, berani dalam berpendapat, percaya diri dalam persaingan yang dinamis serta mampu menumbuhkan kedisiplinan (Wardhani, 2015).
Problem based learning bertujuan untuk meningkatkan keterampilan belajar yang spesifik misalnya konstruksi pengetahuan dan penalaran Savery (Yamin \& Masek, 2011). Tujuan metode problem based learning (Arends, 2009, hlm. 43) adalah sebagai berikut, (1) Mengembangkan keterampilan berpikir dan kemampuan memecahkan masalah banyak ide yang digunakan untuk mengartikan tentang kemampuan berpikir (2) Problem based learning mendorong peserta didik untuk tidak berpikir konkret melainkan berpikir mengenai ide-ide abstrak. (3) Mengembangkan keterampilan belajar secara mandiri. (4) Berbeda dengan pembelajaran konvensional peran guru dalam metode problem based learning cenderung sedikit. (4) Dapat meniru peran orang dewasa.

Langkah-langkah menggunakan metode pembelajaran tersebut, dan ada 5 langkah dalam metode Problem based learning (PBL) Menurut (Nafiah \& Suyanto, 2014) mengemukan bahwa dalam langkah-langkah Problem based learning (PBL) ada 5 tahap yaitu:

1. Guru mempersiapkan dan melempar masalah kepada peserta didik

2. Membentuk kelompok kecil, dalam masing-masing kelompok peserta didik mendiskusikan masalah tersebut dengan memanfaatkan dan merefleksi pengetahuan/keterampilan yang mereka miliki. Suswa juga membuat rumusan masalah dan membuat hipotesis-hipotesis

3. Peserta didik mencari (hunting) informasi dan data yang berhubungan dengan masalah yang sudah dirumuskan

4. Peserta didik berkumpul dalam kelompok untuk melporkan data apa yang sudah diperolah dan mendiskusikan dalam kelompok berdsarkan data-data yang diperoleh tersebut. Langkah ini diulang-ulang sampai memperoleh solusi

5. Kegiatan diskusi penutup sebagai kegiatan akhir, apabila proses sudah memperoleh solusi yang tepat. 


\section{Pemecahan Masalah}

Pemecahan masalah merupakan suatu proses untuk mengatasi kesulitan yang ditemui untuk mencapai suatu tujuan yang diinginkan. Goldstein dan Levin, pemecahan masalah telah didefinisikan sebagai proses kognitif tingkat tinggi yang memerlukan modulasi dan kontrol lebih. Pemecahan masalah merupakan kemampuan berpikir tingkat tinggi yang dimiliki seseorang dengan menggunakan pengetahuan, keterampilan, dan pemahaman untuk menemukan solusi dari masalah yang dihadapinya.

Disamping itu, pemecahan masalah juga merupakan persoalan-persoalan yang dikenal sebagai proses berfikir tinggi dan penting dalam proses pembelajaran. Kemampuan pemecahan masalah sangat penting artinya bagi kehidupan peserta didik dan masa depannya. Para ahli pembelajaran sependapat bahwa kemampuan pemecahan masalah dalam batas-batas tertentu, dapat dibentuk melalui bidang studi dan disiplin ilmu yang diajarkan (Hadi \& Radiyatul, 2014). Pada hakikatnya, program pembelajaran bertujuan tidak hanya untuk memahami dan menguasai apa dan bagaimana sesuatu itu terjadi, lebih dari itu juga peserta didik dituntut untuk memberikan pemahaman dan penguasaan tentang apa yang terjadi, dan bagaimana hal tersbut terjadi. Berdasarkan pada permasalahan yang terjadi tersebut maka pembelajaran pemecahan masalah menjadi sangat penting untuk diajarkan pada peserta didik disekolah. Supaya peserta didik bisa menyelesaikan masalah maka diperlukan sikap dalam menyelesaikan masalah. Namun, masalah dapat muncul ketika skenario berubah, atau ketika seseorang ingin mencapai tujuan tertentu, sehingga diperlukan untuk mengubah keadaan saat ini (Tsai, 2017).

Pemecahan masalah merupakan usaha untuk mencari jalan keluar dari suatu kesulitan, perlu adanya tahapan-tahapan dalam pemecahan masalah. Menurut (Polya, 1980, hlm. 5) ada empat tahap pemecahan masalah yaitu; (1) memahami masalah, (2) merencanakan pemecahan, (3) melaksanakan rencana, (4) memeriksa kembali Diagram pemecahan masalah Polya dapat dilihat pada Gambar 1 sebagai berikut.

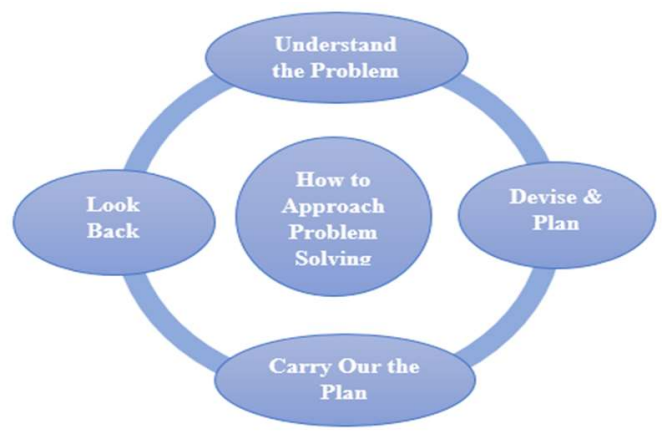

Gambar 1. Diagram Pemecahan masalah Polya

Dari diagram tahapan pemecaham masalah diatas, dapat dirincikan sebagai berikut (Polya, 1980, hlm. 5-17):

1. Memahami masalah (understand the problem)

Tahap pertama pada penyelesaian masalah adalah memahami soal. Peserta didik perlu mengidentifikasi apa yang diketahui, apa saja yang ada, jumlah, hubungan dan nilainilai yang terkait serta apa yang sedang mereka cari. Beberapa saran yang dapat membantu peserta didik dalam memahami masalah yang kompleks: (1) memberikan pertanyaan mengenai apa yang diketahui dan dicari, (2) menjelaskan masalah sesuai dengan kalimat sendiri, (3) menghubungkannya dengan masalah lain yang serupa, (4) fokus pada bagian yang penting dari masalah tersebut, (5) mengembangkan metode, dan (6) menggambar diagram.

2. Membuat rencana (devise a plan)

Peserta didik perlu mengidentifikasi operasi yang terlibat serta strategi yang diperlukan untuk menyelesaikan masalah yang diberikan. Hal ini bisa dilakukan peserta didik dengan cara seperti: (1) menebak, (2) mengembangkan sebuah metode, 
mensketsa diagram, (4) menyederhanakan masalah, (5) mengidentifikasi pola, (6) membuat tabel, (7) eksperimen dan simulasi, (8) bekerja terbalik, (9) menguji semua kemungkinan, (10) mengidentifikasi sub-tujuan, (11) membuat analogi, dan (12) mengurutkan data/informasi.

3. Melaksanakan rencana (carry out the plan) Apa yang diterapkan jelaslah tergantung pada apa yang telah direncanakan sebelumnya dan juga termasuk hal-hal berikut: (1) mengartikan informasi yang diberikan ke dalam bentuk matematika; dan (2) melaksanakan strategi selama proses dan perhitungan yang berlangsung. Secara umum pada tahap ini peserta didik perlu mempertahankan rencana yang sudah dipilih. Jika semisal rencana tersebut tidak bisa terlaksana, maka peserta didik dapat memilih cara atau rencana lain.

4. Melihat kembali (looking back)

Aspek-aspek berikut perlu diperhatikan ketika mengecek kembali langkah-langkah yang sebelumnya terlibat dalam menyelesaikan masalah, yaitu: mengecek kembali semua informasi yang penting yang telah teridentifikasi; (2) mengecek semua perhitungan yang sudah terlibat; (3) mempertimbangkan apakah solusinya logis; (4) melihat alternatif penyelesaian yang lain; dan (5) membaca pertanyaan kembali dan bertanya kepada diri sendiri apakah pertanyaannya sudah benar-benar terjawab.

Sementara itu, menurut (Krulik dan Rudnick, 1995), ada lima tahap yang dapat dilakukan dalam memecahkan masalah yaitu sebagai berikut:

1. Membaca (read). Aktifitas yang dilakukan peserta didik pada tahap ini adalah mencatat kata kunci, bertanya kepada peserta didik lain apa yang sedang ditanyakan pada masalah, atau menyatakan kembali masalah ke dalam bahasa yang lebih mudah dipahami.

2. Mengeksplorasi (explore). Proses ini meliputi pencarian pola untuk menentukan konsep atau prinsip dari masalah. Pada tahap ini peserta didik mengidentifikasi masalah yang diberikan, menyajikan masalah ke dalam cara yang mudah dipahami.

3. Memilih suatu strategi (select a strategy). Pada tahap ini, peserta didik menarik kesimpulan atau membuat hipotesis mengenai bagaimana cara menyelesaikan masalah yang ditemui berdasarkan apa yang sudah diperoleh pada dua tahap pertama.

4. Menyelesaikan masalah (solve the problem). Pada tahap ini semua keterampilan matematika seperti menghitung dilakukan untuk menemukan suatu jawaban.

5. Meninjau kembali dan mendiskusikan (review and extend). Pada tahap ini, peserta didik mengecek kembali jawabannya dan melihat variasi dari cara memecahkan masalah.

Dari paparan di atas dapat disimpulkan bahwa tahapan dalam pemecahan masalah antara lain, (1) Identifikasi masalah yang ada, (2)Menentukan tujuan apa yang akan dilakukan untuk menyelesaikan masalah, (3) Membuat strategi dalam penyelesaian masalah, (4) Mempraktikan stsrategi yang telah dibuat. (4) Memeriksa kembali hasil yang didapatkan

\section{Metode Penelitian \\ Desain Penelitian}

Metode yang digunakan dalam penelitian ini adalah kuasi eksperimen (quasi eksperiment) untuk mengetahui efek atau hasil dari perlakuan (treatmet) yang dilakukan.. Alat yang digunakan dalam penelitian ini adalah tes dan kuisoner yang dibagikan kepada peserta didik kelas XI IIS. Sedangkan prosedur penelitian ini diawali dengan melakukan studi pendahuluan di SMA Negeri 1 Rengasdengklok untuk mengumpulkan data awal yang berkaitan dengan penelitian yaitu dengan wawancara guru mata pelajaran Ekonomi kelas XI IIS, dan melakukan analisis pra penelitian. Selanjutnya merumuskan masalah yang akan diteliti, setelah itu peneliti melakukan studi literatur untuk memecahkan masalah yang dihadapi dalam hal ini penerapan metode problem based learning.

\section{Subjek Penelitian}

Penelitian ini dilakukan di SMA Negeri 1 Rengasdengklok kabupaten Karawang. Subjek dalam penelitian in adalh peserta didik kelas XI IIS 1 yang berjumlah 32 peserta didik dan kelas XI IIS 2 yang berjumlah 33 peserta didik. Sehingga peneliti dapat membagi tiap kelas menjadi kelas kontrol dan kelas eksperimen. Kelas kontrol adalah kelas XI IIS 1, dimana peserta didik diberikan tretament berupa metode pembelajaran konvensional, dan kelas 
ekperimen adalah kelas XI IIS 2 yang diberikan treatment berupa metode problem based learning. Pendekatan yang digunakan dalam penelitian ini adalah pendekatan kuantitatif.

\section{Instrument Penelitian}

Instrumen dalam penelitian ini berupa tes soal essai yang akan diberikan kepada peserta didik, peneliti juga menyiapkan beberapa soal atau instrumen dan jawaban instrumen yang telah disiapkan untuk diberikan kepada peserta didik. Tes berupa soal (pre test) diberikan kepada kelas kontrol dan kelas eksperimen sebelum perlakuan (treatment) dilakukan. Kemudian, setelah dilakukan treatment yang dilakukan kepada kelas XI IIS 1 dengan menggunakan metode konvensional dan kelas XI IIS 2 menggunakan metode problem based learning, peserta didik diberikan soal essai (post test) yang sama dengan soal sebelumnya yaitu pada (pret test) untuk mengethaui peningkatan hasil yang didapatkan oleh peserta didik sebelum dan setelah adanya perlakuan (tretament). Penyusuna tes dilakukan dengan pembuatan kisi-kisi soal, kemudian dilanjutkan dengan penyusunan soal, hingga membuat kunci jawaban soal dan pemberian skor kepada masing-masing soal. Pemberian skor kemampuan pemecahan peneliti mengacu pada indikator yang digunakan oleh (Utami, 2016), yaitu menunjukkan pemahaman masalah $(0 \%$ $20 \%$ ), merancang strategi pemecahan masalah (0\%-40\%, melaksanakan strategi pemecahan masalah (0\%-20\%, memeriksa kebenaran jawaban $(0 \% 20 \%)$. Penjelasan dari pedoman skor tersebut dapat dijelaskan dalam Tabel 2.

\section{Tabel 2. Pedoman Penskoran Pemecahan Masalah}

\begin{tabular}{|l|c|}
\hline \multicolumn{1}{|l|}{ Respon Peserta didik Terhadap Soal atau Masalah } & Skor \\
\hline Tidak Menjawab & 0 \\
\hline $\begin{array}{l}\text { Terdapat Kesalahan dalam jawaban dan tidak tidak } \\
\text { disertai perincian }\end{array}$ & 4 \\
\hline Terdapat kesalahan dalam jawaban tapi disertai perincian & 8 \\
\hline Memberi jawaban yang mendekati benar dan rinci & 16 \\
\hline Memberi jawaban yang benar dan rinci & 20 \\
\hline Skor Maksimum = 20 \\
\hline
\end{tabular}

Sumber: Adopsi dari Exfarina Sri Utami (2016)

\section{Teknis Analisis Data}

Uji Validitas dan Realibilitas

Validitas adalah suatu ukuran yang menunjukkan kevalidan atau kesahihan suatu instrument. Jadi pengujian validitas itu mengacu pada sejauh mana suatu instrument dalam menjalankan fungsi. Sebelum tes dilakukan peneliti terlebih dahulu melakukan uji coba dengan menggunakan instrumen berupa soal essai yang telah dibuat sebelumnya untuk mengetahui, intrumen tersebut bisa digunakan atau tidak dalam penelitian ini. Setelah instrumen dinyatakan valid, makan peneliti akan langsung menguji realibilitas dengan menggunakan spss 23.

Uji Normalitas

Uji normalitas digunakan untuk mengetahui kondisi data apakah berdistribusi normal atau tidak (Nurudin et al., 2014). Kondisi data berdistribusi normal menjadi syarat untuk pengujian hipotesis menggunakan statistik paramentrik.
$H_{0}$ : Data berdistribusi normal

$H_{a}$ : Data tidak berdistribusi normal

Berdasarkan rumusan hipotesis tersebut, dengan taraf signifikansi 0,05 , kriteria pengujiannya adalah jika nilai signifikansi < 0,05 maka data berdistribusi tidak normal dan $H_{0}$ ditolak, sedangkan jika nilai signifikansi > 0,05 maka data berdistribusi normal dan $H_{0}$ diterima

Uji Hipotesis

Hipotesis yang dirumuskan dalam penelitian ini menggunakan analisis statistik inferensial parametris two-way ANOVA (two factors model), penelitian eksperimen digunakan untuk menguji main dan interaction effect . Main effect adalah pengaruh variabel independen (metode problem based learning) terhadap variabel dependen (kemampuan pemecahan masalah), sedangkan interaction effect merupakan gabungan (joint effect) dua atau lebih variabel independen (metode based learning) terhadap variabel dependen 
Santi, Ikaputera Waspada, Sumartini $\mid$ Pengaruh Penggunaan Metode .....

(kemampuan pemecahan masalah). Selanjutnya asumsi menggunakan rumus ANOVA apabila dalam analisis data yang digunakan tidak homogen dan normal, anova tetap robust (kuat) untuk tetap digunakan. Perhitungan hipotesis penelitian menggunakan uji ANOVA dengan bantuan software komputer SPSS versi 23. Kriteria pengujiannya adalah:

1. Jika nilai sig (signifikansi) atau nilai probabilitas < 0,05 maka hipotesis penelitian yang di ajukan HA diterima dan H0 ditolak.

2. Jika nilai sig (signifikansi) atau nilai probabilitas $>0,05$ maka hipotesis penelitian yang di ajukan HA ditolak dan H0 diterima.

Adapun hipotesis statistik penelitian adalah sebagai berikut: (1) Tidak terdapat perbedaan kemampuan pemecahan masalah peserta didik yang menggunakan metode problem based learning dengan metode konvensional; (2) Terdapat perbedaan kemampuan memecahkan masalah peserta didik yang menggunakan metode problem based learning dengan metode konvensional

\section{Hasil dan Pembahasan \\ Deskripsi Data Hasil Penelitian}

Kemampuan pemecahan masalah peserta didik pada penelitian yang dilakukan oleh peneliti kali ini melibatkan dua kelas, yaitu kelas eksperimen XI IIS 1 menggunakan metode Problem Based Learning dan kelas Kontrol XI IIS 2 menggunakan metode konvensional (ceramah tanya jawab), dimana metode ceramah tanya jawab ini sering digunakan oleh guru dalam menyampaikan materi dalam pembelajaran ekonomi. Dalam ata-rata post test dibawah ini, penelitian ini setiap kelas diberikan perlakuan sebanyak 4 kali pertemuan, guna mengetahui kemampuan pemecahan masalah peserta didik pada materi perpajakan baik kelas eksperimen maupun kelas kontrol. Diakhir pertemuan peneliti melakukan pengujian metode yang telah digunakan yaitu dengan cara memberikan soal intrumen berupa soal essai yang disesuaikan dengan indikator pemecahan masalah, dengan jumlah soal 5 soal essai yang harus diselesaikan oleh peserta didik pada kelas eksperimen maupun kelas kontrol dengan soal yang sama.

Kemampuan Pemecahan Masalah Peserta didik Kelas Eksperimen dan Kelas Kontrol

Perbedaan kemampuan pemecahan masalah peseta didik pada kelas eksperimen dan kelas kontrol dapat dilihat dari hasil post test yang dilakukan oleh peneliti diakhir pertemuan penelitian. Berdasarkan hasil tes tersebut diperoleh skor tes kemampuan pemecahan masalah peserta didik dilihat dari skor minimum dan maksimum yang diperoleh baik di kelas eksperimen maupun dikelas kontrol. Jumlah peserta didik dikelas XI IIS 1 dan kelas XI IIS 2 berjumlah 67 peserta didik. Proses penelitian dilakukan dengan mengamati guru yang memberikan perlakuan pada kelas eksperimen dengan menggunakan metode Problem Based Learning dan kelas kontrol menggunakan metode ceramah tanya jawab.

Untuk dapat melihat perbedaan nilai kemampuan Pemecahan masalah peserta didik dikelas eksperimen dan kelas kontrol dapat dilihat dari Gambar 2 perbedaan rata-rata pretest dan posttest dibawah ini,

Gambar 2.

Perbedaan Rata-Rata Nilai Pretest Dan Posttest Kemampaun Pemecahan Masalah Siswa

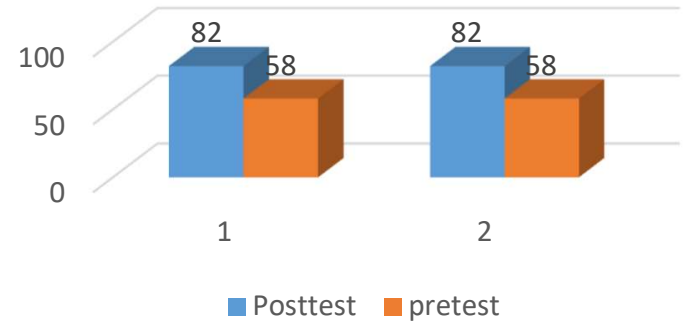


Berdasarkan gambar 2. Menunjukan rata-rata hasil pretest dan posttest siswa di SMA Negeri 1 Rengasdengklok. Gambar tersebut menunjukan bahwa nilai rata-rata skor kemampuan pemecahan masalah siswa sebelum adanya perlakuan (treatment) pada pretetst yaitu sebesar 58. Sedangkan setelah adanya perlakuan (treatment) dengan menggunakan metode problem based learing rata-rataskor hasil posttest meningkat yaitu sebesar 82. Hal tersebut berarti menunjukan adanya $\mathrm{N}$-Gain sebesar 24 , yang artinya adalah metode problem based learning berpengaruh terhadap kemampuan pemecahan masalah siswa dibandingkan dengan metode ceramah. Hal tersebut sejalan dengan penelitian yang telah dilakukan oleh sujiono dkk (2017) yang menyatakan bahwa metode problem based learning berpengaruh terhadap kemampuan pemcahan masalah siswa, selain sujiono Fitriani dkk (2020) juga menyatakan bahwa metode problem based learning berpengaruh positif terhadap kemampuan pemecahan masalah siswa.

\section{Pengaruh Metode Problem Based Learning terhadap Kemampuan Pemecahan Masalah}

Pengajuan hipotesis juga menunjukan bahwa terdapat perbedaan peningkatan kemampuan pemecahan masalah peserta didik dengan menggunakan metode problem based learning dengan metode konvensional (ceramah tanya jawab) pada mata pelajaran

\section{Referensi}

Agustin, V. N. (2013). Peningkatan Aktivitas Dan Hasil Belajar Siswa Melalui Model Problem Based Learning (Pbl). Journal of Elementary Education, 2(1), 36-44.

Amir, M. Taufik. 2010. Inovasi Pendidikan Melalui Problem Based Learning: Bagaimana Pendidik Memberdayakan Pembelajaran di Era Pengetahuan. Jakarta: Prenada Media Group.

Arends, R.I. 2009. Learning To Teach. New York: McGraw Hill.

Alan, U. F., \& Afriansyah, E. A. (2017). Kemampuan Pemahaman Matematis Siswa Melalui Model Pembelajaran ekonomi dengan sub materi perpajakan. Penelitian ini membuktikan bahwa metode problem based learning dapat meningkatkan kemampaun pemecahan masalah dibandingkan dengan metode konvensional.

Kemampaun pemecahan masalah peserta didik dikelas eksperimen dan kelas kontrol sebenrnya sama-sama memiliki pengaruh positif, akan tetapi hasil dari kemampuan pemecahan masalah peserta didik dengan menggunakan metode problem based learning menunjukan peningkatan lebih tinggi dibandingkan metode konvensional (ceramah, tanya jawab). Kesimpulan

Jadi, kesimpulan dari penelitian ini, menunjukan bahwa terdapat perbedaan peningkat kemampuan pemecahan masalah peserta didik dengan menggunakan metode problem based learning dibandingkan dengan metode konvensional (ceramah tanya jawab). Kemampuan pemecahan masalah peserta didik dengan menggunakan metode problem based learning menunjukan peningkatan lebih tinggi dibandingan dengan menggunakan metode konvensional (ceramah, tanya jawab).

Berdasarakan kesimpulan dari penelitian yang dilakukan, peneliti menyarankan kepada guru ekonomi atapun peneliti selanjutnya untuk senantiasa mengaplikasikan metode problem based learning pada mata pelajaran ekonomi.

Auditory Intellectualy Repetition Dan Problem Based Learning. Jurnal Pendidikan Matematika, 11(1). https://doi.org/10.22342/jpm.11.1.3890.6 7-78

Beetlestone, F. (2011). Creative Learning: Imaginative Teaching ab Narulito Yusron. Nusa Media. Bandung.

Fitriani, A., Zubaidah, S., Susilo, H., \& Al Muhdhar, M. H. I. (2020). The effects of integrated problem-based learning, predict, observe, explain on problem-solving skills and selfefficacy. Eurasian Journal of Educational Research, 20(85), 4564. 
Fernandes, R. (2019). Relevansi Kurikulum 2013 dengan kebutuhan Peserta didik di Era Revolusi 4.0. SOCIUS, 6(2), 70-80.

Hadi, S., \& Radiyatul, R. (2014). Metode Pemecahan Masalah Menurut Polya untuk Mengembangkan Kemampuan Siswa dalam Pemecahan Masalah Matematis di Sekolah Menengah Pertama. EDU-MAT: Jurnal Pendidikan Matematika, 2(1), 53-61. https://doi.org/10.20527/edumat.v2i1.603

Krulik, Stephen dan Rudnick, Jesse A. 1995. The New Sourcebook for Teaching Reasoning and Problem Solving in Elementary School. Boston: Temple University.

Mursidik, E. M., Samsiyah, N., \& Rudyanto, H. E. (2015). Kemampuan Berpikir Kreatif Dalam Memecahkan Masalah Matetatika Open-Ended Ditinjau Dari Tingkat Kemampuan Matematika Siswa Sekolah Dasar. PEDAGOGIA: Jurnal Pendidikan, 4(1), 23. https://doi.org/10.21070/pedagogia.v4i1. 69

Nafiah, Y. N., \& Suyanto, W. (2014). Penerapan model problem-based learning untuk meningkatkan keterampilan berpikir kritis dan hasil belajar siswa. Jurnal Pendidikan Vokasi, 4(1), 125-143. https://doi.org/10.21831/jpv.v4i1.2540

Nurudin, M., Mara, M. N., \& Kusnandar, D. (2014). Ukuran sampel dan distribusi sampling dari beberapa variabel random kontinu. 03(1), 1-6.

Oktavianti, S., Farida, F., \& Putra, F. G. (2018). Implementasi Model Osborn Dengan Teknik Mnemonic Melalui Teori Konstruktivisme Terhadap Kemampuan Pemecahan Masalah Matematis. MaPan, 6(1), 94-103. https://doi.org/10.24252/mapan.2018v6n 1a9

Pendidikan, J., Jpm, M., \& Vol, R. (2017). Kemampuan Berpikir Kritis Matematis Mahasiswa Melalui Pendekatan Konstruktivisme Pada Matakuliah Matematika Keuangan. Jurnal Pendidikan Matematika RAFA, 1(2), 306-325.

Polya, G. 1980. On Solving Mathematical Problems in High School. New Jersey: Princeton Univercity Press.
Sujiono, S., Handoyo, B., \& Ruja, I. N. (2018). Memecahkan masalah geografi melalui problem-based learning. Jurnal Teori dan Praksis Pembelajaran IPS, 2(2), 6875.

Sumantri, B. A. (2019). Pengembangan Kurikulum di Indonesia Menghadapi Tuntutan Kompetensi Abad 21. AtTa'lim: Media Informasi Pendidikan Islam, 18(1), 27-50.

Tilaar, H. A. R. (1998). Beberapa agenda reformasi pendidikan nasional dalam perspektif abad 21. Indonesia Tera.

Tsai, M. H., \& Tang, Y. C. (2017). Learning attitudes and problem-solving attitudes for blended problem-based learning. Library Hi Tech, 35(4), 622-635.

Utami, Exfarine S. (2016). Pengaruh metode Guided Discoveri Leraning Terhadap Kemampuan Pemecahan Masalah dengan Variabel Kemandirian Belajar. Bandung: Pascasarjana Universitas Pendidikan Indonesia.

Wardhani, P. A. (2015). Efikasi Diri Dan Pemahaman Konsep IPA Dengan Hasil Belajar Ilmu Pengetahuan Alam Siswa Sekolah Dasar Negeri Kota Bengkulu, 6(5), 188-194. https://doi.org/10.1017/CBO9781107415 324.004

Wijaya, E. Y., Sudjimat, D. A., \& Nyoto, A. (2016). Transformasi Pendidikan Abad 21 Sebagai Tuntutan Pengembangan Sumber Daya Manusia di Era Global. Jurnal Pendidikan, 1, 263-278. http://repository.unikama.ac.id/840/32/26 3-278 Transformasi Pendidikan Abad 21 Sebagai Tuntutan Pengembangan Sumber Daya Manusia Di Era Global.pdf. diakses pada; hari/tgl; sabtu, 3 November 2018. jam; 00:26, wib.

Wijayanto, M. (2009). Pengaruh Penerapan Model Problem Based Learning Dan Cooperative Learning Terhadap Prestasi Belajar Matematika Ditinjau Dari Motivasi Belajar Siswa. https://doi.org/10.1017/CBO9781107415 324.004

Yamin, S., \& Masek, A. (2011). The Effect of Problem Based Learning on Critical Thinking Ability: A Theoretical and 
Empirical Review. International Review

of Social Sciences and Humanities, 2(1),

215-221. www.irssh.com 